\title{
The action of anti-inflammatory drugs on the fertility of female rats with intrauterine contraceptive devices
}

\author{
J. Testart and A. Gauthier \\ Laboratoire de Physiologie et Psychologie de la Reproduction Humaine, INSERM U 187, \\ Hôpital Antoine Béclère-157 rue de la Porte de Trivaux, 92141 Clamart, France
}

\begin{abstract}
Summary. A silk thread (0-0) or a copper wire (0.18 mm diameter) was placed in the left uterine horn of rats, at least 3 days before fertilization. The animals were untreated or given daily injections of $3 \mathrm{mg}$ hydrocortisone or $30 \mathrm{mg}$ aspirin beginning the day after insertion of the IUD; 2 weeks after coitus, the animals were killed.

A longitudinal $(\leqslant 10 \mathrm{~mm})$ silk thread and the copper wire were effective IUDs regardless of treatment. With the short silk thread $(\leqslant 2 \mathrm{~mm})$, implantation occurred in all groups of rats but a high failure rate was observed in hydrocortisone-treated rats (5/9 with implantations). The no. of implantations/no. of corpora lutea $(\times 100)$ was much higher $(20.4 \%)$ in rats treated with aspirin and hydrocortisone than in untreated animals $(3.2 \%)(P<0.01)$.

We conclude that the effectiveness of an IUD can be altered by treatment with an anti-inflammatory substance.
\end{abstract}

\section{Introduction}

One of the modes of action of intrauterine contraceptive devices (IUDs) in animals, as in women, is to produce an inflammatory reaction involving leucocytic infiltration (Greenwald, 1965; Parr, 1969, 1970; Moyer \& Mishell, 1971). Leucocytes (principally neutrophilic granulocytes) are present on the surface of IUDs removed from the uterus of women (Sagiroglu \& Sagiroglu, 1970). As well as prostaglandins (Hillier \& Kasonde, 1976; Myatt, Chaudhuri, Gordon \& Elder, 1977) leucocytes may release substances such as $\beta$-galactosidase, the concentration of which in the uterine fluid reflects the extent of the inflammation and may be sufficient to be toxic to the young embryo (Parr \& Shirley, 1976). The fact that the mechanical dispersion of granulocytes associated with the mouse embryo (see Hurst, Jefferies, Eckstein \& Wheeler, 1977) allows normal development to occur in vitro (Hurst, Jefferies, Dawson \& Eckstein, 1978) confirms that the leucocytic invasion is involved in the degeneration of the embryo before implantation occurs. In the female rabbit fitted with an IUD, fertility is inversely related to the leucocyte concentration in uterine washings (El Sahwi \& Moyer, 1971). The inflammatory process therefore represents an important mode of action of an IUD.

The possible relationship between contraceptive failure in women and the absorption of anti-inflammatory drugs has been investigated (Zerner, Miller \& Festino, 1976; Thomas, 1977), but the degree of importance of this effect has yet to be thoroughly examined. The present study with rats was thus designed to verify the effectiveness of different types of IUD in association with treatment with anti-inflammatory drugs. 


\section{Materials and Methods}

The Wistar rats were virgin females aged 4-6 months and weighed about $300 \mathrm{~g}$. They were kept under controlled lighting conditions ( $14 \mathrm{~h}$ light $/ 24 \mathrm{~h}, 06: 00-20: 00 \mathrm{~h}$ ). The numbers of animals in each treatment group are shown in Table 1. The IUDs were inserted without regard to the stage of the oestrous cycle. The females were anaesthetized with an i.m. injection of $0.3 \mathrm{ml} \mathrm{Hypnorm}$ (Uva, Paris), containing $0.2 \mathrm{mg}$ fentanyl $/ \mathrm{ml}$ and $10 \mathrm{mg}$ fluanisone/ml; at laparotomy the IUD was inserted $1 \mathrm{~cm}$ from the utero-tubal junction on the left side. The silk thread (0-0) (Fandre, Nancy) in Group 2 was inserted longitudinally through the lumen for 5-10 $\mathrm{mm}$ and knotted outside the uterus. In Group 3 the silk thread $(0-0)$ was placed transversely across the lumen and knotted outside the uterus. The copper wire $(0.18 \mathrm{~mm}$ diameter and $10 \mathrm{~mm}$ length) used for Group 4 was inserted transversely as for Group 3 and was closed with a ring outside the horn as described by Chang, Tatum \& Kincl (1970). Half of the animals in Group 1(a) were sham-operated in that a silk thread was placed transversely in the left horn and immediately removed.

Table 1. The numbers of animals in the various treatment groups

\begin{tabular}{|c|c|c|c|c|c|}
\hline \multirow[b]{2}{*}{ Group } & \multirow[b]{2}{*}{ IUD } & \multicolumn{3}{|c|}{ Treatment } & \multirow[b]{2}{*}{ Total } \\
\hline & & $\begin{array}{c}\text { (a) } \\
\text { None }\end{array}$ & $\begin{array}{c}\text { (b) } \\
\text { Aspirin } \\
\text { (30 mg/day) }\end{array}$ & $\begin{array}{c}\text { (c) } \\
\text { Hydrocortisone } \\
(3 \mathrm{mg} / \text { day })\end{array}$ & \\
\hline 1 & None & 24 & 28 & 9 & 61 \\
\hline 2 & Longitudinal silk thread & 14 & 7 & 12 & 33 \\
\hline 3 & Transverse silk thread & 11 & 13 & 9 & 33 \\
\hline \multirow[t]{2}{*}{4} & Transverse copper wire & 6 & 9 & 10 & 25 \\
\hline & Total & 55 & 57 & 40 & 152 \\
\hline
\end{tabular}

In each of the 4 groups the rats were given a daily intramuscular injection at $08: 00 \mathrm{~h}$ of (a) $0.2 \mathrm{ml}$ saline $(9 \mathrm{~g} \mathrm{NaCl} / \mathrm{l})$, (b) $30 \mathrm{mg}$ lysine acetyl salicylate (Egic, Montargis, France) in $0.2 \mathrm{ml}$ saline, or (c) $3 \mathrm{mg}$ hydrocortisone hemisuccinate (Roussel, Paris, France) in $0.2 \mathrm{ml}$ saline. The injections were started the day after laparotomy and were continued until the animals were killed.

On the 3rd day after the injections were started, the females were paired with a male in a cage with a wire-mesh bottom. Mating was inferred from the presence of a vaginal plug and the females were killed by cervical dislocation 12-16 days later.

Immediately after death the numbers of corpora lutea in the ovaries and the numbers of live (beating heart) and dead fetuses in the uterus were counted. The implantation rate (no. of implantation sites/no. of corpora lutea) and the survival rate (no. of live embryos/no. of implantation sites) were determined. All data summaries are expressed as means with s.e.m.; statistical significance of differences was assessed by Student's $t$ test for differences between the means and $\chi^{2}$ test for differences between the rates.

\section{Results}

The delay between laparotomy and copulation was 4-7 days in $57(55 \%)$ of the 103 operated females, 3 days in 1 rat and 8-29 days in 45 rats. The mean delay was not different among the experimental groups according to the IUD used $(10.71 \pm 2.42,9.34 \pm 1.01,7.79 \pm 1.02$ and $8.88 \pm 0.98$ days for Groups $1,2,3$ and 4 respectively), or the drug treatments $(8.72 \pm 0.99$, $7.30 \pm 0.72$ and $9.97 \pm 1.19$ days for Treatments (a), (b) and (c) respectively). There was no 
difference in fertility between the 12 non-operated animals and the 12 sham-operated animals in Group 1(a): the ovulation rates were $6.00 \pm 0.38$ and $6.04 \pm 3.34$, the implantation rates were 93.8 and $89.1 \%$ and the embryonic survival rates were 92.5 and $96.0 \%$ respectively.

As shown in Table 2, the number of corpora lutea in the hydrocortisone-treated rats was significantly higher $(P<0.05$, Student's $t$ test $)$ than in the other groups. The number of ovulations in animals with IUDs did not vary according to the type of IUD used $(6.25 \pm 0.39$ in Group 2, 5.84 \pm 0.32 in Group 3 and $6.30 \pm 0.40$ in Group 4). The implantation rate and the embryo survival rate in Group 1(a) and the right horns of Groups 2, 3 and 4 (i.e. horns without an IUD) were similar (85.4, 90.0 and $87.5 \%$, and $94.0,91.0$ and $90.5 \%$ for Treatments (a), (b) and (c) respectively).

Table 2. The effects of anti-inflammatory drugs on fertility in rats

Treatment

$\begin{array}{lll}\text { (a) None } & \text { (b) Aspirin } & \text { (c) Hydrocortisone }\end{array}$

\begin{tabular}{|c|c|c|c|}
\hline No. of animals & 55 & 57 & 40 \\
\hline No. of ovulations & 660 & 689 & 527 \\
\hline $\begin{array}{l}\text { Mean } \pm \text { s.e.m. } \\
\text { ovulations/ovary }\end{array}$ & $6.00 \pm 0 \cdot 18$ & $6.04 \pm 0.16$ & $6.59 \pm 0.17^{*}$ \\
\hline Implantation rate $(\%) \dagger$ & & & \\
\hline Both horns of Group 1 & $91 \cdot 3(48)$ & $90 \cdot 0(56)$ & $90 \cdot 2(18)$ \\
\hline Right horns of Groups $2+3+4$ & $76 \cdot 3(31)$ & $89.8(29)$ & $85 \cdot 8(31)$ \\
\hline \multicolumn{4}{|l|}{ Survival rate $(\%)$} \\
\hline Both horns of Group 1 & $94 \cdot 3$ & $90 \cdot 8$ & 90.9 \\
\hline Right horns of Groups $2+3+4$ & $93 \cdot 2$ & $91 \cdot 3$ & 89.9 \\
\hline
\end{tabular}

* Significantly different from values for Treatments (a) and (b), $P<0.05$ (Student's $t$ test).

$\dagger$ No. of horns in parentheses.

The effects of the IUDs are shown in Table 3. Amongst the 31 rats not treated with anti-inflammatory drugs (Treatment (a)), there was only one case of IUD failure. The contraceptive effect of the longer silk thread (Group 2) was not affected by any of the treatments. The copper IUD was effective as a contraceptive except for 1 of the rats treated with hydrocortisone (Group 4(c)). There was a slight failure of contraception in Group 3(a) animals (i.e. untreated) and Group 3(b) animals (aspirin). These values did not differ but the implantation rate for Group 3(c) rats (hydrocortisone) was significantly greater than that for Group 3(a) $\left(P<0.001, \chi^{2}\right.$ test $)$. When both treatments with anti-inflammatory drugs were

Table 3. The effects on fertility of a longitudinal silk thread (Group 2), transverse sik thread (Group 3) and copper wire (Group 4) in rats treated daily with (a) saline only, (b) $30 \mathrm{mg}$ aspirin or (c) $3 \mathrm{mg}$ hydrocortisone

\begin{tabular}{|c|c|c|c|c|c|c|c|c|c|}
\hline & \multicolumn{3}{|c|}{ Group 2} & \multicolumn{3}{|c|}{ Group 3} & \multicolumn{3}{|c|}{ Group 4} \\
\hline & (a) & (b) & (c) & (a) & (b) & (c) & (a) & (b) & (c) \\
\hline No. of animals & 14 & 7 & 12 & 11 & 13 & 9 & 6 & 9 & 10 \\
\hline No. of ovulations on left side & 78 & 47 & 84 & 63 & 74 & 58 & 36 & 52 & 66 \\
\hline $\begin{array}{l}\text { No. of animals with implantations } \\
\text { in left horn }\end{array}$ & 0 & 0 & 0 & 1 & 3 & 5 & 0 & 0 & 1 \\
\hline $\begin{array}{l}\text { No. of implantations in left horn } \\
\text { Implantation rate }(\%)\end{array}$ & - & - & - & $\begin{array}{l}2 \\
3 \cdot 2\end{array}$ & $\begin{array}{l}10 \\
13 \cdot 5\end{array}$ & $\begin{array}{l}17 \\
29 \cdot 3^{*}\end{array}$ & - & - & $\begin{array}{l}3 \\
4 \cdot 5\end{array}$ \\
\hline Survival rate (\%) & & & & 100 & 100 & 88.2 & & & 0 \\
\hline
\end{tabular}


considered (Groups $3(\mathrm{~b})+3(\mathrm{c}))$, the implantation rate $(20.4 \%)$ was significantly higher $(P<$ 0.01 ) than that for untreated females (Group 3(a): $3 \cdot 2 \%$ ).

Although the implantation rate in uterine horns containing the IUD was much lower than in the contralateral horn the embryonic survival rate was comparable, except for Group 4(c).

\section{Discussion}

The fact that the IUD per se does not alter the rate of ovulation in a number of mammals, including the rat, is well known (Marston \& Chang, 1965). We cannot explain the increased ovulatory response after treatment with hydrocortisone, but the increase was only small. The difference was not related to the duration of treatment because ovulation in rats treated with aspirin or hydrocortisone occurred at similar post-operative times (about 8 days). The females were placed with males very shortly after the IUD insertions to limit the duration of treatment with the anti-inflammatory drugs because in preliminary experiments several females had suffered from internal haemorrhage, particularly during treatment with aspirin.

Peppler \& Molony (1977) gave the anti-inflammatory drug, dexamethasone, orally to female rats for a period of 2 weeks before mating; there was no alteration of the effect of the IUD and it was concluded that the effectiveness of the IUD is not related to an inflammatory process. However, it is possible that dexamethasone may not exert an effect at the uterine level when administered orally. In the present study the anti-inflammatory drugs were given by intramuscular injection. Treatment with hydrocortisone caused failure of a transverse silk thread in $5 / 9$ females but had no effect with the longitudinal thread and only a slight effect with the copper device (1/10 females implanting). There were successful inplantations in all the treatment groups with the transverse silk thread. Doyle \& Margolis (1965) found that a 5-0 thread was not effective as a contraceptive, but we observed an effectiveness of nearly $90 \%(10 / 11)$ in non-treated females fitted with a thicker thread (0-0).

The dose levels used for the anti-inflammatory drugs were related to the limit levels used in man: $10 \mathrm{mg} / \mathrm{kg} / \mathrm{day}$ for hydrocortisone and $100 \mathrm{mg} / \mathrm{kg} / \mathrm{day}$ for aspirin. The relationship between the copper surface area of the IUD and the weight of the uterus was also approximately the same as that found in the clinical context in women: about $1 \mathrm{~mm}^{2}$ copper surface area in a uterine horn weighing $0.5 \mathrm{~g}$ in the female rat as compared with $200 \mathrm{~mm}^{2}$ of copper surface area for a human uterus of about $100 \mathrm{~g}$ after one or several pregnancies. However, the single failure of the copper IUD seen in the 10 rats treated with hydrocortisone is not negligible; Chang et al. (1970) considered that an IUD similar to that used in these experiments but having a smaller diameter $(0.1 \mathrm{~mm})$ was completely effective in the rat.

Several authors have pointed out that anti-inflammatory drugs are not able to impede some aspects of the inflammatory process occurring after IUD insertion. Greenwald (1965) observed an increase in leucocytic response inside the IUD-bearing horn of rats treated with phenylbutazone or cortisone acetate. The uterine hypertrophy provoked by an IUD was not prevented by hydrocortisone (Parr \& Segal, 1966; Chaudhuri, 1975) but was reduced by aspirin treatment (Chaudhuri, 1975). We confirm our earlier results (Testart \& Fresno-Chavez, 1971) and suggest that drugs commonly used in women may limit the effectiveness of an IUD and thus explain certain failures of this contraceptive method. However, the way anti-inflammatory drugs act on IUD failure needs further investigation.

We thank the staff of the Station de Physiologie Animale (INRA, Jouy-en-Josas) for looking after the animals. Financial assistance was provided by Searle Laboratories (Montrouge, 92128, France) and Shering Laboratories (Rungis, 94528, France). 


\section{References}

Chang, C.C., Tatum, H.J. \& Kincl, F.A. (1970) The effect of intrauterine copper and other metals on implantation in rats or hamsters. Fert. Steril. 21, 274-278.

Chaudhuri, G. (1975) Inhibition by aspirin and indomethacin of uterine hypertrophy induced by an IUD. J. Reprod. Fert. 43, 77-81.

Doyle, L.L. \& Margolis, A.J. (1965) Intrauterine foreign body studies in rodents. In Proc. 2nd Int. Conf. on Intrauterine Contraception, pp. 185-188. Eds S. J. Segal, A. L. Southam \& K. D. Shafer. Excerpta Medica, Amsterdam.

El Sahwl, S. \& Moyer, D.L. (1971) The leukocytic response to an IUFB in the rabbit. Fert. Steril. 22, 398-408.

Greenwald, G.S. (1965) Interruption of pregnancy in the rat by a uterine suture. J. Reprod. Fert. 9, 9-17.

Hillier, K. \& Kasonde, J.M. (1976) Prostaglandin E and $F$ concentrations in human endometrium after insertion of intrauterine contraceptive device. Lancet i, 15-16.

Hurst, P.R., Jefferies, K., Eckstein, P. \& Wheeler, A.G. (1977) Intrauterine degeneration of embryos in IUD-bearing mice. J. Reprod. Fert. 50, 187-189.

Hurst, P.R., Jefieries, K., Dawson, K. \& Eckstein, P. (1978) In-vitro development of preimplantation embryos recovered from IUD-bearing mice. $J$. Reprod. Fert. 54, 413-417.

Marston, J.H. \& Chang, C.C. (1965) Action of intrauterine foreign bodies in the rat and rabbit. In Proc. 2nd Int. Conf. on Intrauterine Contraception, pp. 242-247. Eds S. J. Segal, A. L. Southam \& K. D. Shafer. Excerpta Medica, Amsterdam.

Moyer, D.L. \& Mishell, D.R. (1971) Reactions of human endometrium to the intrauterine foreign body. $A m . J$. Obstet. Gynec. 111, 66-80.

Myatt, L., Chaudhuri, G., Gordon, D. \& Elder, M.G. (1977) Prostaglandin production by leucocytes attached to intrauterine devices. Contraception 15, 589-599.

Parr, E.L. (1969) Intrauterine foreign bodies: a toxic effect of leukocyte extracts on rat morulae in vitro. Biol. Reprod. 1, 1-10.

Parr, E.L. (1970) Leukocytes and infertility. J. Reprod. Fert., Suppl. 10, 153-170.

Parr, E.L. \& Segal, S.J. (1966) The effect of an intrauterine contraceptive device on the weight of the rat uterus. Fert. Steril. 17, 648-653.

Parr, E.L. \& Shirley, R.L. (1976) Embryotoxicity of leukocyte extracts and its relationship to intrauterine contraception in humans. Fert. Steril. 27, 10671077.

Peppler, R.D. Molony, T. (1977) Effect on an anti-inflammatory compound on IUD effectiveness. Anat. Rec. 187, 775, Abstr.

Sagiroglu, N. \& Sagiroglu, E. (1970) Biological mode of action of the Lippes loop in intrauterine contraception. Am. J. Obstet. Gynec. 106, 506-515.

Testart, J. \& Fresno-Chavez, C. (1971) Action des corticostéroides sur l'ovo-implantation chez la ratte, en présence d'un corps étranger intra-utérin. $C$. $r$. hebd. Séanc. Acad. Sci. Paris D 273, 820-822.

Thomas, P.R. (1977) Stérilet et anti-inflammatoires: à propos de 4 observations. Concours méd. 45, 7095-7096.

Zerner, J., Miller, B.A. \& Festino, M. (1976) Failure of an intrauterine device concurrent with administration of corticosteroids. Fert. Steril. 27, 1467-1468.

Received 2 March 1981 